\title{
Organic farming: Present status, scope and prospects in northern India
}

\author{
Sartaj A. Wani ${ }^{*}$, Muneeb Ahmad Wani ${ }^{2}$, Sheikh Mehraj ${ }^{3}$, Bilal A. Padder ${ }^{3}$, Subhash Chand ${ }^{1}$ \\ ${ }^{* 1}$ Division of Soil Science, Faculty of Agriculture, Sher-e-Kashmir University of Agricultural Sciences and Tech- \\ nology of Kashmir, Wadura, Sopore -193201 (J\&K), INDIA \\ Division of Floriculture \& Landscape Architecture, Sher-e-Kashmir University of Agricultural Sciences and Tech- \\ nology of Kashmir, Shalimar Srinagar - 190025 (J\&K), INDIA \\ ${ }^{3}$ Division of Fruit Science, Sher-e-Kashmir University of Agricultural Sciences and Technology of Kashmir, Shali- \\ mar Srinagar - 190025 (J\&K), INDIA \\ *Corresponding author. E-mail: drsartajsoil@gmail.com
}

Received: November 20, 2015; Revised received: May 19, 2017; Accepted: October 18, 2017

\begin{abstract}
Organic agriculture has emerged as an important priority area globally in view of the growing consciousness for safe and healthy food, long term sustainability and environmental concerns despite being contentious in history. Green revolution although paved way for developing countries in self-sufficiency of food but sustaining production against the limited natural resource base demands has shifted steadily from "resource degrading" chemical agriculture to "resource protective" organic agriculture. The essential concept remains the same, i.e., to go back to the arms of nature and take up organic farming to restore the loss. Organic farming emphasizes on rotating crops, managing pests, diversifying crops and livestock and improving the soil. The rainfed areas particularly north-eastern regions where least or no utilization of chemical inputs due to poor resources provides considerable opportunity for promotion of organic farming thereby reflecting its vast but unexplored scope. However, significant barriers like yield reduction, soil fertility enhancement, integration of livestock, marketing and policy etc., arise at both macroscopic and microscopic levels; making practically impossible the complete adoption of 'pure organic farming'; rather some specific area can be diverted to organic farming and thus a blend of organic and other innovative farming systems is needed. Adoption of Integrated Green Revolution Farming can be possible to a large extent, where the basic trends of green revolution are retained with greater efficiency and closer compatibility to the environment. This review paper attempts to present the recent global and regional scenario of organic farming particularly highlighting the scope, prospects and constraints in the northern areas.
\end{abstract}

Keywords: Environment, Green revolution, INM, Organic farming, Sustainability

\section{INTRODUCTION}

The approach towards global food security is considered now a matter of grave concern around the world. Food and Agricultural Organisation (FAO) has cautioned that though organic farming helps to produce nutritious food and represents a growing source of income for developed and developing nations, it alone cannot ensure global food security (FAO, 2007). Green Revolution (GR) technologies, supported by policies and fuelled by agrochemicals, machinery and irrigation are known to have enhanced agricultural production and productivity but at the same time have taken a toll on natural resources and has led to loss of natural fertility of soils (Kaellander and Rundgren, 2008), dwindling underground water reserves, pest resistance, resurgence of new weeds, loss of friendly insects, altering the environment for producers, workers as well as co consumers (Wani et al., 2013 and Kaur and Kaur, 2014). Intensive farming exacerbates phenomena like soil erosion, loss of organic matter (Montgomery, 2007 and Lal, 2010), considered to be great threat for the future sustainability of crop production on a global scale, especially under extreme climatic events such as droughts. To have a better, efficient and holistic approach towards the global food security, the concept of bio-safety is being implemented at different levels. Organic farming is becoming increasingly important in the agriculture sector at national and global level (Reddy, 2010) exhibiting potential to take care of many problems in an efficient manner (Prasad and Gill, 2009). Organic agriculture is productive and sustainable (Mader et al., 2002) and can improve food security by diversifying on-farm crop and livestock operations, which diversifies income sources and improves variety in diets (Parrott et al., 2006 and Wani et al., 2013). The dual advantage of organic farming being the positive effects on the environment as well as to make the farmer self-sufficient as far as his requirements regarding agro-inputs is concerned (Prasad and Gill, 2009) that too at a reduced price or attractive source of rural income generation (Reddy, 2010 and Shukla et al., 2013). 
Codex Alimentarius Commission defines "organic agriculture as holistic food production management system, which promotes and enhances agro-ecosystem health, including biodiversity, biological cycles and soil biological activity (FAO/WHO, 2013). Ethical issues such as fair labor practices and animal ethics have also been included in organic agriculture definitions (IFOAM, 2002). The main objective of organic farming is to protect human and animal health without contaminating natural sources like water, air and soil (Akgun, 2014). It emphasizes the use of management practices within the system in preference to the use of off-farm inputs (Ramesh et al., 2010) and thus relies on crop rotation, crop residues, animal manure, legumes, green manure, off farming organic waste and aspects of biological pest control (Bhattacharya, 2004 and Wani et al., 2016). It involves diverse crop and livestock rotations, encourages the integration of multiple farm enterprises; encourages the use of leguminous crops for biological nitrogen fixation (Reganold and Watcher, 2016) Organic farming system is based on the management of soil organic matter, which in turn maintains the physical, chemical, and biological properties of soil (Ramesh et al., 2005). Organic farming combines tradition, innovation and science to benefit the shared environment and promote fair relationships and a good quality of life (IFOAM, 2010) and revitalize rural areas through emphasis on promoting a green economy (Pimentel and Patzek, 2005 \& Giampietro and Mayumi, 2009). It reduces pesticide use, fosters soil biological activity, increases species abundance and richness (Hole et al., 2005 and Crowder et al., 2010), reduces soil erosion (Siegrist et al., 1998), increases soil fertility (Leifeld and Fuhrer, 2010), uses less energy and minimizes the gap between NPK addition and removal from the soil (Chhonkar, 2002). On some environmental issues, like soil carbon storage (Wani et al., 2013) or water pollution through nitrate and phosphorus leaching, anthropogenic greenhouse effect through methane and nitrogen oxides emissions, the better environmental performance of organic agriculture is however, not totally unambiguous (Mondelaers et al., 2009 and Crowder et al., 2010). All this is accomplished by using wherever possible, agronomic, biological and mechanical methods as against conventional system involving irrational use of chemical inputs and characterized by a high degree of crop specialization, to fulfil any specific and desired function (FOA, 2007).

\section{CURRENT GLOBAL AND INDIAN SCENARIO}

About $38 \%$ of earth's land cover is occupied by agriculture (FOA, 2015). Although only $1 \%$ of global agricultural land falls under organic production (Willer and Lernoud, 2015), its share of agricultural land and farms continues to grow rapidly. According to the latest survey by the Research Institute of Organic
Agriculture (FiBL) and IFOAM (2016), about 43.1 million hectares of the agriculture land are managed organically on continental basis involving more than 130 countries of the world. Oceania has highest area of 17.3 million hectares (mio ha) followed by Europe (11.6 mio ha), Latin America (6.8 mio ha), Asia (3.6 mio ha), North America (3.1 mio ha) and Africa (1.3 mio ha) reported by Willer et al., (2016), as shown in fig.1. Almost 11 Mha i.e., about one-third of the world's organically managed land is located in the developing countries (Reddy, 2010) involving around $65 \%$ of the developing countries. The percentage of area under organic farming in the total cultivated area of different countries of the world (Table 1) shows Austria $(8.40 \%)$ at the top followed by Switzerland (7.94\%) and UK (4.22\%) (Roychowdhury et al., 2015). The total area under organic certification is 5.71 million hectare. This includes $26 \%$ cultivable area with 1.49 million hectare and rest $74 \%$ (4.22 million hectare) forest and wild area for collection of minor forest produces (FiBL and IFOAM, 2015). More than 60 countries have a regulation on organic foods. Worldwide, 283 organizations offer organic certification services operating in 170 countries (Willer and Lernoud, 2015) and most of the certification bodies fall in Europe (160) followed by Asia (93) and North America (80) as per reports surveyed by IFOAM and SOEL Association (2010). Organic trade is expanding at the rate of $15 \%-20 \%$ per year. A growing number of organic producers are certified through Participatory Guarantee Systems, a more locally focused alternative to traditional certification (Willer and Lernoud, 2015) involving around 10,000 small operators world-wide (Yadav, 2010). Thirty-six percent of the world's organic producers are in Asia, followed by Africa (29\%) and Europe (17\%) (Deshmukh and Babar, 2015). Today at least 141 countries produce organic food commercially (Reddy, 2010) and over 150 countries are exporting certified organic products. High demand for organic foods in Europe and North America has resulted in the import of organic foods from large farms in less-developed countries (Willer and Lernoud, 2015). According to Willer and Lernoud (2015), the countries with largest organic markets include the US (approximately $44 \%$ of the global market) followed by the European Union (approximately 41\%) and and China (2.4 billion euros). The highest market shares reached in Denmark (8 percent), Switzerland (6.9 percent) and Austria (6.5 percent).

The Government of India launched the National Programme for Organic Production (NPOP) developed under the guidelines of international organic production standards such as CODEX and International Federation of Organic Agricultural Movements (IFOAM) (Deshmukh and Babar, 2015) with prime objective of promoting organic farming by facilitating access to organic inputs, streamlining 


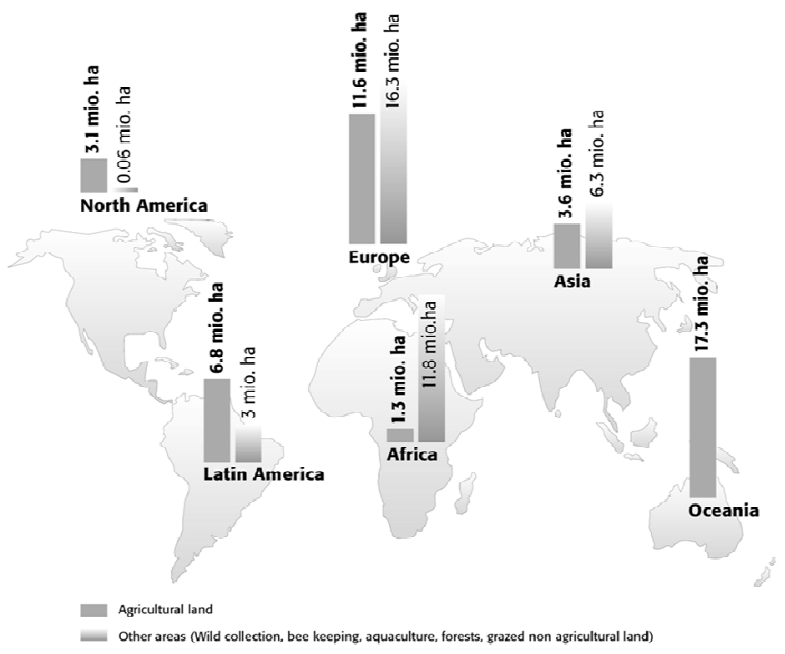

Fig. 1. Area under organic agriculture worldwide (Source: FiBL Survey, 2016).

production, facilitating certification and developing domestic markets for organic commodities (Devarajaiah et al., 2009). Since most certification standards originated in temperate developed countries, they are not always applicable in other regions, especially in less-developed countries and continue to evolve with changing technologies and socio-ecological conditions; some requirements are based on scientific evidence, whereas others are driven by ideology (Reganold and Watcher, 2016). The European Commission and United States Department of Agriculture (USDA) have recognized NPOP standards and conformity assessment procedures of accreditation as equivalent to their country standards. With such recognition, the Indian organic products duly certified by the accredited certification bodies are accepted by the importing countries (Reddy, 2010). Today, India alongside the EU, the U.S., Japan, Brazil, Argentina and Switzerland have adopted organic standards and put in place an inspection and certification mechanism (Chadha, 2008). In order to promote participatory certification of organic farming in a cluster approach, Paramparagat Krishi Vikas Yojana (PKVY) was formulated in year 2014-15. Many state-supported agencies, non-governmental organizations (NGOs) and individuals are involved in the promotion of organic farming in India. Currently, India ranks 33rd in terms of total land under organic cultivation and 88th in agricultural land under organic crops to total farming area (Reddy, 2010). Nearly 4.72 million hectares has been brought under organic certification processes, including 0.6 million ha of cultivated agricultural land and 4.12 million ha for wild harvest collection in forests (Yadav, 2015) involving around 6 lakh farmers. India ranks 10th among the top ten countries in terms of cultivable land under organic certification and fifth largest country in having organic wild collection area and bee pastures (Willer and Kilcher 2009). Madhya Pradesh has highest area under organic farming (1.1 mha or 52\%), followed by Maharashtra (0.96 mha or 33.6\%) and Orissa (0.67 mha or $9.7 \%)$. With the sizable acreage under naturally organic/default organic cultivation, India has tremendous potential to grow crops organically and emerge as a major supplier of organic products in the world's organic market (Eximbank, 2002). The demand for organic food is increasing steadily in both the developed and developing countries at an annual average growth rate of 20-25 per cent (Ramesh et al., 2005) and with rise in consciousness it is fetching ground in India and establishing a good export market. Oil seeds (50\%) lead among the food products exported followed by processed food products $(25 \%)$, cereals and millets $(17 \%)$, tea $(2 \%)$, pulses $(2 \%)$, spices $(1 \%)$, dry fruits (1\%) (Deshmukh, 2015) and their value added products as well (Nandi et al., 2015). The organic products export realization was around 374 million US $\$$ registering a $4.38 \%$ growth over the previous year. Organic products are exported to all the continents of the world of which the largest share goes to EU $(44.12 \%)$, followed by Canada $(21.57 \%)$, USA $(19.18 \%)$ and Asian countries (12.70\%) (APEDA, 2014 and Deshmukh, 2015).

\section{TREND OF ORGANIC FOOD CONSUMPTION IN INDIA}

The marketing of food is a matter of consideration as the production of food is determined by the vagaries of temperature as well as the various marketing constraints at national level as well as international level. The scope for marketing organic food in India is vast and still yet unexplored to its full potential. India experienced good growth in the organic business sector, with exports reportedly growing between 25 and 30 percent and domestic markets growing at about 40 percent (Hill, 2016). Two initiatives were launched by India's central government: allocation of 100 crore rupees for organic market development in the Northeast and launch of the government's Participatory Guarantee Systems (PGS) programme with a pledge of 300 crore rupees for 2015-16 (OFAI, 2016). Domestic market is also growing at an annual growth rate of 15$25 \%$. India produced around 1.35 million MT (201516) of certified organic products which includes all varieties of food products namely sugarcane, oil seeds, cereals \& millets, cotton, pulses, medicinal plants, tea, fruits, spices, dry fruits, vegetables, coffee, cotton, fibre etc. (Yadav, 2015). Though 50\% of the organic food production in India is targeted towards exports, there are many who look towards organic food for domestic consumption (Rekha and Neeraj, 2013) and the increasing trend in organic food consumption is evident from the fact that many organic food stores are 
Table 1. Percentage of area under organic farming in the total cultivated area of different countries of the world (Roychowdhury et al., 2015) .

\begin{tabular}{ccc}
\hline $\begin{array}{l}\text { S. } \\
\text { No. }\end{array}$ & Country & $\begin{array}{c}\text { Percentage of area } \\
\text { under organic farming }\end{array}$ \\
\hline 1 & USA & 0.23 \\
2 & UK & 4.22 \\
3 & Germany & 4.10 \\
4 & Argentina & 1.70 \\
5 & Austria & 8.40 \\
6 & Australia & 2.20 \\
7 & Japan & 0.10 \\
8 & Switzerland & 7.94 \\
9 & South Africa & 0.05 \\
10 & Italy & 3.70 \\
11 & India & 0.03 \\
12 & Pakistan & 0.08 \\
13 & Srilanka & 0.05 \\
\hline
\end{tabular}

mushrooming in India. In India, consumers prefer organic marmalade, organic strawberry, organic tea, organic honey, organic cashew butter and organic flour (Rekha and Neeraj, 2013). The pattern of organic food consumption in India is much different than in the developed countries. However, for interest of consumers the purchase decisions of organic food products are affected by external factors such as certification, labelling, packaging and accessibility which have influence on the awareness of the consumers (Janssen and Hamm, 2012). The differences exist between groups of consumers with respect to their experience in consuming organic products and the extent of available information on these food products (Ergonul and Ergonul, 2015). In this review the stress has been laid on to find out the various opportunities and avenues for promotion of organic farming in north -eastern region.

\section{SCOPE AND PROSPECTS OF ORGANIC FARMING}

India is one of the leading fruit producing countries in the world, producing about $10 \%$ of the world's fruit production (Indian Horticulture Database, 2014). With agriculture as the backbone of the economy supported by the fact that nearly $67 \%$ of population and $55 \%$ of the total work force depending on agriculture and other allied activities, agriculture has the tremendous potential to meet the threshold for satisfying the needs of India's increasing population. It has been estimated that agricultural growth of $4 \%$ or more is required for India to achieve a double digit GDP growth rate (Chandrashekar, 2010). The scope and prospects of potential organic farming in India is signified by the fact that the farm sector has abundant organic resources like livestock, crop residue, water, aquatic weeds, forest litter, urban, rural solid wastes and agro industries, bio-products (Bhattacharya and Chakraborty, 2005). The adherence of huge population of the farmer to the natural law in ancient India has helped in maintaining the soil fertility over a relatively longer period of time (Chandra and Chauhan, 2004). Inherent advantages such as its varied agro-climatic regions, local self-sustaining agri-systems, sizeable number of progressive farmers and ready availability of inexpensive manpower translate into the potential to cultivate organically a vast basket of products (Munda, 2006). More than $65 \%$ of the country's cultivated area is rainfed on crop rotation, crop residues, animal manure, legumes and biological pest control. Most of the farms in remote and marginal areas are subsistence type. Organic farming is growing rapidly among Indian farmers and entrepreneurs, especially in low productivity areas, rain-fed zones, hilly areas and the northeastern states where fertilizer consumption is less than $25 \mathrm{~kg} / \mathrm{ha} /$ year (Mitra and Devi, 2016). In fact, North Eastern Region (NER) is considered as home to some niche crops like Assam lemon, Joha rice, medicinal rice and passion fruits which has high market demands and accounts for 45 per cent of total pineapple production in India (Munda et al., 2007). Uttaranchal and Northeast states have declared themselves "organic- farming states" where as Mizoram and Sikkim declared their intentions to move to total organic farming (Mitra and Devi, 2016). Sikkim has become India's first fully organic state by implementing organic practices on approximately 75,000 ha of agricultural land (Sikkim, 2016). In Nagaland, 3000 ha area is under organic farming while as Meghalaya has committed to certifying 200,000 hectares of land as organic by 2020 ((Hill, 2016). These regions receive very high rainfall $(2000 \mathrm{~mm}$ to $11000 \mathrm{~mm}$ per annum) and thus lead to abundant production of biomass including weeds, shrubs and herbs (Munda, 2006) when a large part of the falls under pastures, forests, wastelands etc. Lotter et al. (2003) reported that organic farming is better in areas having extreme rainfall because of the higher absorption and less run-off water in the field. The promotion of organic farming is advocated initially in the rain-fed areas particularly in the hilly areas having little or no use of chemical fertilizers and other agro-chemicals due to poor resources with small holder farmers (nearly $60 \%$ of farms in India are less than one ha). The state of $\mathrm{J} \& \mathrm{~K}$ is mostly a hilly terrain and majority of its area suffers from massive soil erosion and run-off losses. Besides, more than 70 per cent of the arable land is un-irrigated where cultivation of crops alone is very risky (Gupta et al., 2005 and Chandra, 2014). The varied agro-climatic zones with potential of diversification makes possible to convert at least these areas into organic farming easily (Wani et al., 2013). Some awakening has started 
in the state, with the success of organic farming in western and southern states like Karnataka and Maharashtra (Khanna, 2012).

\section{CONSTRAINTS}

Low amount of nutrients and high $\mathrm{C}$ : $\mathrm{N}$ ratio of different organic residues: Organic nutrient sources like farmyard manure, compost, poultry manure, straw, etc contain very low amount of nutrients, not sufficient to meet the nutrient requirements of crops thereby forming a large gap exists between the available potential and their utilization. Slow release especially when temperature remains low for most period of crop growth makes the synchronization of nutrient release and their uptake by crop plants a difficult task. Although many organic residues like paddy straw, wheat straw, sugarcane trash, can be used to make up the plant nutrients need yet they have a wider $\mathrm{C}: \mathrm{N}$ ratio. If they are not fully decomposed and added as such, will cause immobilization of nutrients. Therefore, it is not possible to meet the nutrient requirements of crops entirely from organic sources, if $100 \%$ cultivable land is converted to organic farming.

Low yield of crops: With the use of organic sources of nutrients, the yield of the crop is very low (Kaur and Toor, 2015), especially during initial stages, although it may stabilize later, yet complete dependence on pure organic farming will not be sustainable in the long run. Small holding and poor farmers: Most farmers in Jammu \& Kashmir are outlined as small holdings and poor. They are not directly connected to markets to buy or sell food (Chandra, 2014 and Kaur and Toor, 2015). Since organic farming's main attraction is export, small farmers are less able to compete when the international trade brings down prices even in local markets.

Market and Infrastructural problems and lack of target (institutional) groups: Market development, especially domestic markets, continues to be one of the biggest challenges facing organic agriculture. Closed corner location, remoteness and isolation from major markets are the prime constraints. Lack of supply and a narrow product variety leads to lack of interest by actors throughout the supply chain, inhibiting consumer demand and creating an obstacle to procurement by public and private institutions. High consumer prices may also limit consumer interest (Kaellander and Rundgren, 2008). There is tremendous lack of infrastructural facilities for processing, packing, storage etc. to meet the organic standards (Kaur and Toor, 2015) and to avoid contamination of organically produced food. On one hand, target groups of organic food products such as big hotels, restaurants, airlines, cafes, etc. which can afford to pay premium prices for high quality organic foods are completely lacking. On the other hand, common people cannot afford to pay higher prices for organically produced food indicating low domestic consumption.

Control of weeds: Organic sources of nutrients promote profuse proliferation of weeds that compete with the plants for different nutrients, space, light, water, etc. On the other hand, weedicides cannot be used in organic farming, and thus economic weed control remains a challenge in organic farming.

Scarcity of biomass: Readily available and abundant organic sources are not enough to meet the requirements of composts, vermicomposts etc. A lot of organic wastes and plant residues get lost in the fields either because of difficulty in collection or to handle or use properly. Moreover, people in rural areas use plant residues like straw, stubbles, pruned material and cow dung for producing charcoal as an energy source, because dependence on other energy sources like LPG, diesel, petroleum products etc, proves costly (Sharma et. al., 2011).

High input costs: Local or farm renewable organic resources like neem cakes, groundnut cakes, cow dung, earthworms, etc are becoming costlier day by day than the conventional or industrially produced chemical fertilizers \& pesticides. Chemical fertilizers are easier to purchase given the farmer has purchasing power.

Lack of awareness: There is lack of awareness and knowledge about modern methods or techniques of composting, vermicomposting etc., among the farmers from the preparation as well as application point of view and thus both quality and efficacy are poor at the end (Chandra, 2014 and Kaur and Toor, 2015).

Benchmark survey: A great challenge in organic farming promotion is the benchmark survey for identifying the potential areas in north eastern regions and other regions in India as well.

Certifying oriented problems: Before producing marketable products an organic farm has to have a transition period of 1 to 3 years depending upon the certifying agency's requirements and during this period the farmers have to grow the crops as per standards set for organic farming and thus produce about 3/4 th of the normal yield. Yet they have to market the produce in the open general market. Small and marginal farmers can hardly afford to do so. Moreover, the farmers won't opt for certification because of the costs involved as well as the extensive documentation that is required by certifiers.

\section{Conclusion}

Keeping in view the aforesaid advantages and limitations of organic farming in northern areas in India, following generalisations can be made in the context of farming.

Himachal Pradesh, endowed with unique and diverse forms of flora and fauna, is storehouse of a large array of diversity in food, fodder, vegetables, and horticulture, forest and medicinal plants that grow in valleys, hill 
terraces with agro climatic zones varying from sub-tropical sub-mountain to dry temperate high hills, provide conducive conditions for production of wide range of crops; wide variation in agro-climatic parameters; prevailing traditional farming system; rich indigenous knowledge base; self-sustaining agriculture production system; availability of skilled manpower, low consumption of chemical fertilizer and pesticides, offers ample scope for organic farming

Wherever it possible, organic farming can be encouraged especially in horticultural crops where its effects have been found better. For example in Kashmir, walnut cultivation is purely organic based horticultural crop and of high quality has tremendous export potential in the international market. Similarly, almond can be grown with no use of chemical fertilizers. So the areas under walnut cultivation can be considered as 'organic by default'.

Himachal farmers so far benefit from, off season tag to vegetables; cash crops; niches based crops, such as peas and exotic vegetables grown in higher reaches of the State, the premium quality fruit of cold desert zone (apple of Kinnaur and spiti). The niche value of these commodities will be further enhanced by producing them organically. It is in these areas and for these commodities that certified organic tag or Himachal organic brand will add further value (Tej and Vaidya, 2006).

North Eastern Region (NER) is home to some niche crops like Assam lemon, Joha rice, medicinal rice and passion fruits which have high market demands, accounts for 45 percent of total pineapple production in India. It is the fourth largest producer of oranges in India. One of the best quality ginger (low fiber content) produced in the North Eastern Region.

Sikkim is the largest producer of large cardamom (54 per cent share) in the world and Agri-Export Zone (AEZ) for ginger. AEZ is set up in Tripura for organic cultivation of pineapple. Assam tea is known for its quality worldwide.

Since Jammu \& Kashmir is mostly a hilly state, there are a number of farms in the uplands, especially in the Kandi belts where use of agro-chemical fertilizers, pesticides is practically very less either due to their belief or economic reasons and farmers depend entirely on organic sources of nutrients for production. For example potato cultivation in Shopian and Anantnag and Kaala zeera production in Gurez (Bandipora) (Chandra, R. 2014). Such areas can be considered as "relatively organic".

'Floating gardens' or 'Floating islands' of Kashmir formed from weeds of Dal Lake are of much importance for the production of vegetables. In these gardens, most versatile organic manure added by houseboat owners is the hydrilla muck. Water hyacinth and other aquatic weeds are also used. Not even a single fertilizer is added for vegetables production. However, vegetable production in these gardens cannot be sustainable at a large scale that too for commercial purposes, keeping environmental conservation and heritage preservation in consideration.

Flowers and some aromatic \& medicinal plants like Lavender, Geranium, etc can be grown without even organic fertilizers and can generate employment through entrepreneurship, besides having good export potential for their quality (Chandra, 2014). Organic Lavender best oil yielding and versatile industrial crop and Organic Geranium for oil can be cultivated for high export potential.

Similarly, the vegetable production in Leh and Kargil districts of Ladakh region is based on organic fertilizers like processed night soil compost in the field called Chaksa. Use of chemical fertilizers is hardly preferred for vegetable production because of greater irrigation needs as well as lesser connectivity due to hilly terrain (Hussain et al., 2012).

\section{EPILOGUE}

Organic farming has the twin objective of the system sustainable and environmental sensitivity. In order to achieve these two goals, it has developed some rules and standards which must be strictly adhered to. There is very little scope for change and flexibility. Thus, organic farming does not require best use of options available rather the best use of options that have been approved. These options are usually more complex and less effective than the conventional system. With ever increasing population having huge food requirements and meagre availability of organic resources and above mentioned constraints "pure Organic Farming" is not possible; (Elliot and Mumford, 2002 and $\mathrm{Wu}$ and Sardo, 2010) rather some specific area can be diverted to organic farming for export of high quality horticultural and plantation crops in context of farming in northern states. We can use all the organics that are available but we are not going to feed six billion people with organic fertilizers. Thus, adoption of 'Pure Organic Farming' is possible partially, more specifically crops having high export potential in International markets (Swaminathan et. al., 2007) and will become less relevant in the future (Pickett, 2013). On the other hand, full adoption of Integrated Green Revolution Farming, another option of Organic Farming can be possible to a large extent, where the basic trends of the green revolution such as intensive use of external inputs, increased irrigation, development of high yielding and hybrid varieties as well as mechanizations of labour are retained with much greater efficiency on the use of these inputs with limited damage to the environment and human health. For this purpose some techniques are developed and combined with the high input technology in order to create Integrated Systems such as, "Integrated Nutrient Management" (INM), "Integrated Pest 
Management" (IPM) and biological control methods which reduce the need for chemicals (Elliot and Mumford, 2002 and Bhattachary and Chakraborty, 2005).

\section{REFERENCES}

APEDA, (2014). Organic production and current scenario in India. http:// www.apeda.gov.in/apedawebsite/organic/ Organic_Products.htm

Bhattacharya, P. and Chakraborty, G. (2005). Current status of organic farming in India and other countries. Indian Journal of Fertilizers, 1(9):111-123

Bhattacharya, P. (2004). Organic Food Production in India Status, Strategy and Scope. Agribios (India), Jodhpur, $01-182$

Chadha, K.L. (2008). Organic Farming: Concept, Initiatives, Status and Implication. In Proceedings of the Padmanav Panda Memorial Oration at Orissa University of Agriculture \& Technology, Bhubaneswar, India.

Chandra, R. (2014). Sustainability through Organic AgroBiotechnology with special reference to Jammu \& Kashmir scenario. International Journal of Genetic Engineering and Biotechnology, 5 (2), pp. 169-178

Chandrashekar, H. M. (2010). Changing scenario of organic farming in India: an overview. Int. NGO J., 5(1): 34 39

Chhonkar, P. K., (2002) "Organic farming myth and reality." in Proceedings of the FAI Seminar on Fertilizer and Agriculture Meeting the Challenges, New Delhi, India

Crowder, D. W., Northfield, T. D., Strand, M. R. \& Snyder, W. E. (2010). Organic agriculture promotes evenness and natural pest control. Nature, 466: 109-112

Deshmukh, M. S. and Babar, N., (2015). Present status and prospects of organic farming in India. European Academic Research 3 (4), 4271-4287

Devarajaiah M. K. and Natraju. M. S. (2009). Financing Agriculture - A National J. Agriculture and Rural Develop., 9: $20-25$

Elliot, S.L., and Mumford, J.D. (2002). Organic, integrated and conventional apple production: Why not consider the middle ground? Crop Protection, 21: 427-429

Ergonul, B., and Ergonul, P. G. (2015). Consumer motivation for organic food consumption. Emirates Journal of Food and Agriculture, 27(5): 416-422

FAO/WHO (Food and Agriculture Organization/World Health Organization). (2013). Codex Alimentarius: Guidelines for the Production, Processing, Labelling and Marketing of Organically Produced Foods. CAC/ GL 32.Paris: FAO/WHO

FAOSTAT. (2010). FAO Statistical Database Domain on Fertilizers: Resource STAT Fertilizers. Food and Agriculture Organisation of the United Nations (FAO) Rome, Italy. Available at Web site http://faostat.fao.org/ site/575/default. aspx\#anchor (accessed 7 October 2009)

Food and Agriculture Organisation of the United Nations (FAO), (2007). Adaptation to Climate Change in Agriculture, Forestry and Fisheries: Perspective, Framework and Priorities.FAO, Rome, Italy

Food and Agriculture Organization of the United Nations (FAO), (2015). Online Database (accessed August 2015); http://faostat.fao.org/site/377/default.aspx\#ancor
Giampietro, M. and Mayumi, K. (2009). The Biofuel Delusion: The Fallacy of Large Scale Agro-biofuels Production. Earthscan, London

Gupta, R. D. Kher, Deepak and Jalali, V.K. (2005). Organic Farming: Concept and Prospective in Jammu and Kashmir. Journal of Research, SKUAST-J, 4: 25-37

Hill, J. K. W. (2016). Organic Agriculture in India and Participatory Guarantee Systems (Pgs): A Case Study From West Bengal. Jharkhand Journal of Development and Management Studies, 14:7037-7055

Hole D. G., Perkins A. J., Wilson J. D., Alexander I. H., Grice P. V., Evans A. D. (2005). Does organic farming benefit biodiversity? Biological Conservation. 122: 113 $-130$

Hussain, N., Mehdi, M., Fatima N. and Mehdi, S.S. (2012). Importance of organic farming and their prospects in Ladakh. Elixir International Journal, (44): 7285-7286

International Federation of Organic Agriculture Movements, First draft of 2002, IFOAM basic standards for organic production and processing. On-line report, Germany, 2001; Tholey-Tholey, www. ifoam.org.

IFOAM (International Movement of Organic Agriculture Movements), (2010). Definition of Organic Agriculture. IFOAM http://www.ifoam.org/ growing organic/ definitions/doa/index.html, and http://www.ifoam.org Accessed on 10 March

IFOAM, FiBL \& SOEL, (2015). About 31 million certified organic hectares worldwide. Federation of Organic Agriculture Movements (IFOAM), Swiss Research Institute of Organic Agriculture (FiBL) and Foundation Ecology and Farming (SOL), Germany

Indian Horticulture Database, (2014). National Horticulture Board, Ministry of Agriculture, Government of India: Gurgaon, India, 2015. Available online: http// www.nhb.gov.in (accessed on 25 October 2015).

Janssen, M. and U. Hamm. (2012). Product labelling in the market for organic food: Consumer preferences and willingness-to-pay for different organic certification logos. Food Qual. Prefer., 25: 9-22

Kaellander, I., and Rundgren, G. (2008). Building sustainable organic sectors. Bonn: IFOAM

Kaur, A. and Kaur, G. (2014). Organic farming for sustainable agriculture: Global and Indian perspective. Global Journal for Research Analysis, 3 (2): 57-58

Kaur, K and Toor, M.S. (2015). Organic Farming: Status and Constraints. Indian J. Econ. Dev., 11 (1): 333-338

Khanna, B. (2012). Organic farming attracts more Punjab peasant. Hindustan Times. May 13, Bathinda.

Lal, R. (2010). Enhancing eco-efficiency in agro-ecosystems through soil carbon sequestration. Crop Sci., 50: 120 131

Leifeld, J. \& Fuhrer, J. (2010). Organic farming and soil carbon sequestration: what do we really know about the benefits? AMBIO: A Journal of the Human Environment, 1-15.

Lotter, D. W., Seidel, R. and Liebhardt, W. 2003. The pPerformance of organic and conventional cropping systems in an extreme climate year. Am. J. Alternative Agr. 18 (3):146-154.

Mader, P., Fliefback, A., Dubois, D. Gunst, L., Fried, P. and Niggili, U. (2002). Soil fertility and biodiversity in organic farming. Science, 296 (5573): 1694-1697

Mitra, S.K. (2013). Organic tropical and subtropical fruit 
production in India-Prospects and challenges. Acta Hort., 975, 303-307.

Mitra, S. and Devi, H., (2016). Organic Horticulture in India, Horticulturae, 2 (17)

Mondelaers, K. U., Aertsens J. U and Huylenbroeck G.U. (2009). A meta-analysis of the differences in environmental impacts between organic and conventional farming. British food journal, 111(10): 1098-1119

Montgomery, D. R. (2007). Dirt: The Erosion of Civilization. University of California Press, Berkeley.

Munda, G.C. (2006). Problems and prospects of Organic farming in NER. Paper presented in the Seminar on "Organic farming - Status and Road Map" during the North East Agri. Expo on March 06 at Dimapur, Nagaland.

Munda, G.C., Ghosh, P.K., Das, Anup., Ngachan, S.V. and Bujarbaruah, K.M. (2007). Advances in Organic Farming Technology in India. ICAR Research Complex for NEH Region, Umaim-793 103, Meghalaya.

Nandi, R., Bokelmanna, W., Nithya, V. G., Dias, G. (2015). Smallholder organic farmer's attitudes, objectives and barriers towards production of organic fruits and vegetables in India: A multivariate analysis. Emirates Journal of Food and Agriculture, 27(5): 396-406

NPOP, (2010). National programme for Organic Production containing the standards for the organic products. Department of Commerce, Ministry of Commerce, Government of India

OFAI (2016). 2 lakh ha area to be covered under organic farming during 2015-18: Govt (source WebIndia). Organic Farming Association of India. Retrieved from http://ofai.org/2016/07/2-lakh-ha-area-to-be-coveredunder-organicfarming-during-2015-18-govt/

Organic farming in India, Eximbank report, 2002; www. Eximbank agro.com.

Parrott, N., Olesen, J. E. \& Hogh-Jensen, H. (2006). In Global Development of Organic Agriculture: Challenges and Prospects (eds. Halberg, N. et al.) 153-179 (CABI)

Pickett, J. A. (2013). Food security: intensification of agriculture is essential, for which current tools must be defended and new sustainable technologies invented. Food Energ. Secur. 2, 167-173

Pimentel, D. and Patzek, T. (2005). Ethanol production using corn, switchgrass, and wood: biodiesel production using soybean and sunflower. Natural Resources Research, $14,65-76$.

Prasad, K and Gill, M.S. (2009). Developments and strategies perspective for organic farming in India. Indian Journal of Agronomy, 54 (2): 186-192

Ramesh, P., Panwar, N.R., Singh A.B., Raman, S., Yadav, S.K., Srivastava, R. and Rao A.S., (2010). Status of organic farming in India. Current Science, 98 (9): 11901194

Ramesh, P., Singh, M. and Subba Rao, A. (2005). Organic farming: Its relevance to the Indian context, Current Science, 88 (4)
Reddy, B. S. (2010). Organic farming: status, issues and prospects - a review. Agric. Econ. Res. Revision, 23:343-358

Reganold, J. P. and Watcher, J. M. (2016). Organic agriculture in the twenty-first century, Nature Plants, 2, 15221

Rekha, M. and Neeraj, K. (2013). Consumer Insights for Organics Food Market: A Delhi-NCR Study, Apeejay Journal of Management and Technology. 8

Roychowdhury, R., Banerjee, U., Sofkova, S. and Tah, J. (2015). Organic farming for crop improvement and sustainable agriculture in the era of climate change. On Line J. Biol. Sci., 13(2): 50-65. doi: 10.3844/ ojbsci.2013.50.65

Sharma, K. and Pradhan, S., (2011). Organic Farming: Problems and Prospects. Yojana, 55: 68-70

Shukla, U. N., Manju, L. M. and K. C. Bairwa. (2013). Organic Farming: Current Status in India Popular Kheti, (1) 4(October-December)

Siegrist, S., Staub, D., Pfiffner, L. and Mader, P. (1998). Does organic agriculture reduce soil erodibility? The results of a long-term field study on loess in Switzerland. Agric Ecosyst. \& Environ., 69, 253-264

Sikkim Becomes India's First Organic State. (2016). Available online: http://www.thehindu.com/news/national/ sikkim-becomes-indias-first-organic state/ article8107170.ece (accessed on 14 January 2016)

Swaminathan, C., Swaminathan, V. and Vijaylakshmi, K. (2007). Panchagavyya-Boon to organic farming. International Book Distributing Co. Lucknow (UP).

Tej, P. and Vaidya, V.S. (2006). Organic Farmers Speak On Economics and Beyond. International Competence Centre for Organic Agriculture (ICCOA), Bangalore, India

Wani, S., Ali, T., Bashir, Z., Kousar, S. \& Rasool, F. (2016).Organic Farming and its Services in Sustainable Agriculture - An Overview Advances in Life Sciences, 5, 9601-9606

Wani, S. A., Chand, S., Najar, G.R. and Teli, M.A. (2013). Organic Farming: As a Climate Change Adaptation and Mitigation Strategy. Current Agriculture Research Journal, 1(1), 45-50

Willer, H. and J. Lernoud. (2015). The World of Organic Agriculture: Statistics and Emerging Trends (Eds). . FIBL-IFOAM Report, Bonn, Germany

Willer, H. and Kilcher L. (Eds.). (2009). The World of Organic Agriculture - Statistics and Emerging Trends 2009. IFOAM, Bonn; FiBL, Frick; ITC, Genf

Willer, H., Lernoud, J. \& Kilcher, L. (eds). (2015). The World of Organic Agriculture: Statistics and Emerging Trends 2016, (FiBL-IFOAM)

$\mathrm{Wu}$, J. Y., and Sardo, V. (2010). Sustainable versus organic agriculture. In: Sociology, Organic Farming, Climate Change and Soil Science. pp. 41-76. Lichtfouse, E., Ed., Springer, Dordrecht

Yadav, A. K. (2015). Organic Agriculture at a Glance. Available online: http://krishijagran.com/farm/scenarioinIndia /2015 /03 / Organic- Agriculture - At- a- Glance (accessed on 2 April 2015). 